\title{
Retention of cemented zirconia copings on TiBase abutments
}

\author{
Oswaldo S. Santos-Neto', Letícia M. Gonçalves², Etevaldo M. Maia-Filho', Adriana S. \\ Malheiros' , Leily M. Firoozmand², Paulo C. M. Villis' ', Andres F. M. Cardenas' , Rudys R. J. \\ Tavarez'
}

1. Universidade CEUMA, Departamento de Pós-Graduação, São Luís, Maranhão, Brasil.

2. Universidade Federal do Maranhão, Departamento de Odontologia I, São Luís, Maranhão, Brasil

\begin{abstract}
This study evaluated the influence of resin cements and glass ionomers on tensile strength and types of failure of zirconia copings cemented on titanium base abutments. Forty-two samples were prepared, which were formed by a Cone Morse implant, a titanium abutment with the fixing screw, and a zirconia structure made using a CAD/CAM system. The samples $(n=42)$ were randomly distributed according to the cementing agent: resin-modified glass ionomer cement (RelyX Luting 2), self-adhesive resin cement (RelyX U200), and self-curing resin cement (Multilink N). After cementation of the copings, half of the samples from each group $(n=7)$ were randomly selected and subjected to thermocycling (5000 cycles). A tensile load test was performed on a universal testing machine until failure occurred $(1 \mathrm{~mm})$. In addition, the type of failure was analyzed using the two-way analysis of variance test and Tukey's post-hoc test ( $\alpha$
\end{abstract}

$=0.05)$. Lower tensile load was observed for the glass ionomer cement $(p<0.001)$ regardless of the evaluation period. After thermocycling, a significant reduction in tensile load values was verified for both evaluated cements $(p=0.047)$. For the resin cements, failures were predominantly of the screw fracture type $(82.1 \%)$ already with the use of glass ionomer cement, and $28.5 \%$ of the failures were of an adhesive type between the zirconia coping and the cement. Resin cements have better stability under tensile load compared to resin glass ionomers when cementing zirconia copings on titanium base abutments.. Received: March 2021; Accepted: June 2121

Keywords: prostheses and implants - dental implant ceramics - resin cements - glass ionomer cements - dental implant abutment interface.

\section{Retenção de copings de zirconia cimentados sobre pilares tibase}

\section{RESUMO}

Este estudo avaliou influência dos cimentos resinosos e a base de ionômero de vidro na resistência à tração e os tipos de falhas de copings de zircônia cimentados sobre pilares TiBase. Foram confeccionadas 42 amostras, sendo estas formadas por implante cone morse, pilar de titânio (TiBase) com o parafuso de fixação e uma estrutura de zircônia (coping de Zr) confeccionado através do sistema CAD/CAM. As amostras $(n=42)$ foram aleatoriamente distribuidas de acordo com o agente de cimentação: (cimento de ionômero de vidro modificado por resina [RelyXTMLuting2]; cimento resinoso autoadesivo [RelyXTM U200] e cimento resinoso autopolimerizavel (Multilink ${ }^{\circledR} N$ ). Após cimentação dos copings, metade das amostras de cada grupo $(n=7)$ foram aleatoriamente selecionadas e submetidas a termociclagem (5000 ciclos). O Teste de resistência a tração foi realizado em uma máquina de ensaio universal, até que ocorresse a falha $(1 \mathrm{~mm} / \mathrm{min})$. Adicionalmente, o tipo de falha foi analizado. Os dados foram analisados pelo teste ANOVA two-way e post teste de Tukey's $(\alpha=0.05)$. Menor média de resistência a tração foi observada para o cimento de ionômero de vidro $(p<0,001)$ independente do periodo de avaliação. Após a termociclagem, foi verificada uma redução significativa nos valores de resistênca a tração, para os cimentos avaliados ( $p=0,047)$. Para os cimentos resinosos, as falhas foram predominantemente do tipo fratura do parafuso $(82,1 \%)$ já com o uso do cimento de ionomero de vidro, 28,5\% das falhas foram de tipo adesiva entre o coping de $\mathrm{Zr}$ e o cimento. Cimentos resinosos apresentam melhor estabilidade na resistência a tração em comparação a ionmeros de vidro resinosos na cimentação de copings de zircônia sobre pilares TiBase.

Palavras-chave: proteses e implantes - implante dentário cerâmicas - cimentos de resina - cimentos de ionômeros de vidro - interface pilar Implante dentário. 


\section{INTRODUCTION}

There has been great technological progress in implantology in recent years. The search for functional and aesthetic results has fostered the development of techniques and materials with high aesthetics and biodynamic performance ${ }^{1}$.

In this context, research on infrastructures using metal-free materials has increased significantly, concomitantly with the advancement of digital dentistry ${ }^{1,2}$. Digital systems for planning and clinical execution have become increasingly frequent in the dental routine ${ }^{1-4}$.

Among the digital systems, CAD/CAM (computeraided design/computer-aided manufacturing) enables planning and execution with the aid of a computer, facilitating the introduction of zirconia $(\mathrm{Zr})$-based ceramics in implant dentistry ${ }^{1-4}$.

$\mathrm{Zr}$ is a material with aesthetic properties of high resistance and good health relationship with periimplant tissues ${ }^{2,3}$. In addition, CAD/CAM enables automation and standardization of the manufacturing process of prosthetic infrastructures, thereby making it possible to manufacture prostheses with high-quality adaptation in a short time ${ }^{1}$. However, the high strength of a Zr-based infrastructure can generate wear when adapted directly to the prosthetic platform of osseointegrated implants ${ }^{4-6}$. It is therefore recommended to use a titanium base (TiBase) between the $\mathrm{Zr}$ and the implant ${ }^{6,7}$, especially when the implant is functional ${ }^{6,8-11}$.

Thus, TiBases that fit the prosthetic platforms of the implants are made with a coronary portion suitable for receiving $\mathrm{Zr}$ infrastructures $(\mathrm{Zr}$ copings). After being made, the $\mathrm{Zr}$ copings are cemented to the TiBase abutment, and the set is fixed to the osseointegrated implant ${ }^{6-8}$. However, there are currently several types of dental cements with different indications and characteristics, raising questions about which cement is the most appropriate and has the best retention and stability ${ }^{9}$. Resin and ionomeric cements have been indicated as materials with high retention and resistance index in the aging process ${ }^{7,10-13}$, and are therefore indicated for the cementation of $\mathrm{Zr}$ copings on the TiBase abutments due to their adhesion and mechanical resistance ${ }^{7,14}$. Although adhesion characteristics between TiBase abutments and various restorative materials have been reported ${ }^{13-15}$, it has not yet been well established which type of cement is the most suitable for cementing $\mathrm{Zr}$ copings on TiBase abutments, and especially their stability over time and the temperature changes that occur in the oral environment.

The aim of the present study was therefore to evaluate the tensile strength of $\mathrm{Zr}$ copings cemented on TiBase abutments with resin-modified glass ionomer cement and various resin cements after thermocycling. The following null hypotheses were tested: (1) there is no difference in tensile strength between the different cements tested, and (2) thermocycling did not influence the tensile strength values of the $\mathrm{Zr}$ copings cemented on the TiBase abutments.

\section{MATERIALS AND METHODS Experimental design}

Forty-two samples were selected, composed of the set: Strong SW® Cone Morse implant (S.I.N, São Paulo SP, Brazil), TiBase abutment (Duotech ${ }^{\circledR}$ S.I.N, São Paulo SP, Brasil). The set was fixed on a steel base to receive the threads of the type of implant used.

For each TiBase abutment, a $\mathrm{Zr}$ coping was manufactured in a standardized manner using a CAD/CAM system, $6 \mathrm{~mm}$ in height and $6 \mathrm{~mm}$ in thickness. The coping was manufactured in a cylindrical shape, with an indentation of $4 \mathrm{~mm}$ in thickness and $2 \mathrm{~mm}$ in height towards the abutment, thus enabling adaptation of the traction device support in this region ${ }^{14,15}$.

The samples $(\mathrm{n}=42)$ were randomly distributed according to the two study variables: 1) cementing agent: (resin-modified glass ionomer cement [RelyX Luting 2], self-adhesive resin cement [RelyX U200], and self-curing resin cement [Multilink N]); and 2) Thermocycling: without thermocycling (after $24 \mathrm{~h}$ of cementation), with thermocycling.

The abutments were digitalized using a bench scanner (inEos X5, Dentsply Sirona, São Paulo, SP, Brazil), and the coping project was designed (CAD software inLab, Dentsply Sirona) ${ }^{15}$.

The thickness of the cement film was designed to be $40 \mu \mathrm{m}$, except at the margins, which were designed to achieve total sealing to the abutment ${ }^{1,16}$.

\section{Surface treatment and cementation}

After milling, all $\mathrm{Zr}$ copings underwent a blasting process with $50 \mu \mathrm{m}$ aluminum oxide $\left(\mathrm{Al}_{2} \mathrm{O}_{3}\right)$ particles at a pressure of 1.0 bar for $10 \mathrm{~s}^{17}$. The 
coping was fixed and manually blasted at an angle of $45^{\circ}$ and a distance of $3 \mathrm{~cm}$ from the jet firing point. Then the copings were washed ultrasonically with distilled water for $180 \mathrm{~s}$, cleaned in $96 \%$ ethanol, and dried with an air jet.

After blasting, all copings were subjected to the surface treatment recommended by the cement manufacturer (Table 1). Subsequently, the cement was manipulated, inserted into the coping, and manually fixed to the TiBase. Initially, digital pressure was applied, and excess cement was removed. Then each sample was subjected to a constant pressure of $20 \mathrm{~N}$ in the center of the occlusal surface for $10 \mathrm{~min}^{16-19}$.

Photopolymerization followed the time recommended by the cement manufacturer (Table 1) and was carried out with a high-intensity LED light device at $1200 \mathrm{~mW} / \mathrm{cm}^{2}$ (VALO Cordless, Indaiatuba, SP, Brazil). A radiometer (Demetron L.E.D, Radiometer, Kerr Sybron Dental Specialties, Middleton, WI, USA) was used to check the light intensity for each of the five specimens.

The specimens were stored in distilled water at $37^{\circ} \mathrm{C}$ for $24 \mathrm{~h}$. Half the specimens in each group $(\mathrm{n}=7)$ were subjected to 5,000 cycles of thermocycling in water baths, at temperatures of $5^{\circ} \mathrm{C}, 37^{\circ} \mathrm{C}$, and $55^{\circ} \mathrm{C}$, with residence times of $30 \mathrm{~s}$ and rest times of $15 \mathrm{~s}^{14}$.

\section{Tensile test}

The tensile test was performed on a universal testing machine (EMIC DL 2000, Paraná, Brazil) at a speed of $1 \mathrm{~mm} / \mathrm{min}$ until cementation failure or screw fracture occurred.

A load cell of $5000 \mathrm{~N}$ was used, in which a steel device was fixed for traction with a retention area for fitting the specimen (Fig. 1). The maximum force used at the time of the cementation failure (T) was recorded in newton $(\mathrm{N})^{14,15}$.

After the test, the specimens were analyzed according to the location of the cement residue in each component ${ }^{16}$, using an optical microscope (SZH-131, Olympus Ltd., Tokyo, Japan) at a magnification of $10 x$.

The type of failure was classified as: adhesive failure between the $\mathrm{Zr}$ surface and the cement; mixed failure, when there was a failure in both interfaces (between the cement and the $\mathrm{Zr}$ and between the cement and the TiBase); or fracture of the screw (when the screw fractured before cement failure).

\section{Statistical analysis}

After verifying the normality of the data (Shapiro Wilk, $p>0.05$ ), all data were analyzed using twoway analysis of variance (cementing agent and thermocycling). The Tukey post hoc test was used to compare between pairs in all analyses. The effect of size was calculated using eta squared $(\eta 2)$ for the independent variables.

Statistical analysis was performed using IBM SPSS Statistics for Windows v.26 (IBM., Armonk, NY,

\begin{tabular}{|c|c|c|}
\hline Cement / Manufacturer / Lot & Composition & Instructions for use \\
\hline $\begin{array}{l}\text { RelyX Luting 2; 3M; } \\
\text { Lot number: } 1929100186\end{array}$ & $\begin{array}{l}\text { Water, HEMA, fluoroaluminosilicate } \\
\text { glass, reducing agents, titanium } \\
\text { dioxide, dispersing agent, BisGMA, } \\
\text { HEMA, water, potassium persulfate, } \\
\text { polyacrylate methacrylate, BHT, } \\
\text { nonreactive } \mathrm{Zr} \text {-Si charge, solubility } \\
\text { modifiers }\end{array}$ & $\begin{array}{l}\text { 1. Mixing of catalyst and base pastes for } 20 \mathrm{~s} \text {. } \\
\text { 2. Insertion in } \mathrm{Zr} \text { coping. } \\
\text { 3. Polymerization for } 5 \mathrm{~s} \text { on each face. }\end{array}$ \\
\hline $\begin{array}{l}\text { RelyX U200; 3M; } \\
\text { Lot number: } 1921800715\end{array}$ & $\begin{array}{l}\text { Glass powder treated with silane, } \\
\text { 2-propenoic acid, 2-methyl, 1,1 '- [1- } \\
\text { (hydroxymethyl) -1,2-ethanodiyl], TEG- } \\
\text { DMA and silane treated with silane, } \\
\text { glass fiber, persulfate sodium and } \\
\text { t-butyl per-3,5,5-trimethylhexanoate. }\end{array}$ & $\begin{array}{l}\text { 1. Application of the Single Bond Universal } 3 \mathrm{M} \text { in } \\
\text { the } \mathrm{Zr} \text { structure. } \\
\text { 2. Mixing of catalyst and base pastes for } 30 \mathrm{~s} \text {. } \\
\text { 3. Insertion in } \mathrm{Zr} \text { coping } \\
\text { 4. Polymerization for } 20 \text { s on each face. }\end{array}$ \\
\hline $\begin{array}{l}\text { Multilink N; IVOCLAR; } \\
\text { Lot number: Y32874 }\end{array}$ & $\begin{array}{l}\text { Bis-GMA, HEMA, UDMA, 2-dimeth- } \\
\text { ylethyl aminoethyl methacrylate, } \\
\text { dibenzoyl peroxide (organic), and in- } \\
\text { organic fillers: barium glass, ytterbium } \\
\text { trifluoride, spheroid mixed oxide and } \\
\text { titanium oxide, catalysts, stabilizers, } \\
\text { and pigments }\end{array}$ & $\begin{array}{l}\text { 1. Application of Monobond } \mathrm{N} \text { in } \mathrm{Zr} \text { coping. } \\
\text { 2. Mix of the catalyst and base pastes for } 20 \mathrm{~s} \text {. } \\
\text { 3. Insertion in } \mathrm{Zr} \text { coping. } \\
\text { 4. Polymerization for } 20 \mathrm{~s} \text { on each face. }\end{array}$ \\
\hline
\end{tabular}




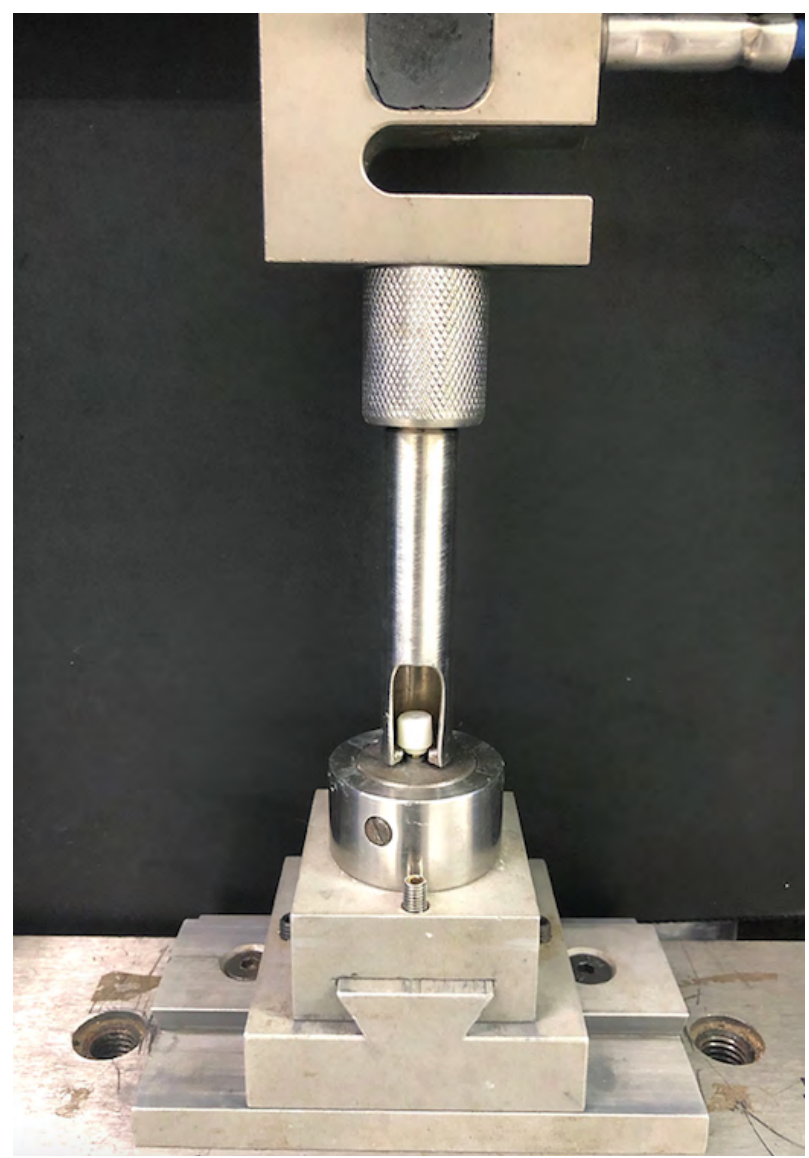

Fig. 1: Steel cylinder set attached to the load cell and sample at the bottom. Zirconia coping with traction insert.
USA). Statistical tests were performed considering a 5\% significance level.

\section{RESULTS}

\section{Analysis of tensile bond strength}

The mean values (standard deviation) demonstrated that the type of cement significantly influenced the recorded tensile load ( $<<0.001)$ (Table 2). The glass ionomer (RelyX Luting 2) showed the lowest value of tensile load ( $\mathrm{p}<0.05)$, whereas the resin cements (RelyX U200 and MultilinkN) did not show a statistically significant difference $(p>$ $0.05)$.

\section{Influence of temperature change on tensile bond strength of cement}

The interaction between the cements and thermocycling was significant $(\mathrm{p}=0.163)$. When subjected to temperature changes (thermocycling), a reduction in the mean values of cement tensile strength $(95 \%$ confidence interval) was observed $(\mathrm{p}$ $=0.047)$. The effect size was 0.760 for the cement type, and 0.105 for the thermocycling variable, i.e., thermocycling was responsible for approximately $10 \%$ of the bond strength variation, and the cement type was responsible for $76 \%$ (Fig. 2).

\begin{tabular}{|c|c|c|c|}
\hline Group & Without thermocycling & Thermocycling & Total \\
\hline RelyX Luting 2 & $752.20(140.93)$ & $569.69(105.31)$ & $660.94(152.49)^{a}$ \\
\hline RelyX U200 & 1150.48 (105.19) & $1170.62(80.94)$ & $1160.55(90.77)^{b}$ \\
\hline MultilinkN & $1174.44(36.16)$ & $1073.84(254.03)$ & $1124.14(181.96)^{b}$ \\
\hline Total & $1025.71(221.46)^{A}$ & $938.05(312.29)^{B}$ & \\
\hline
\end{tabular}

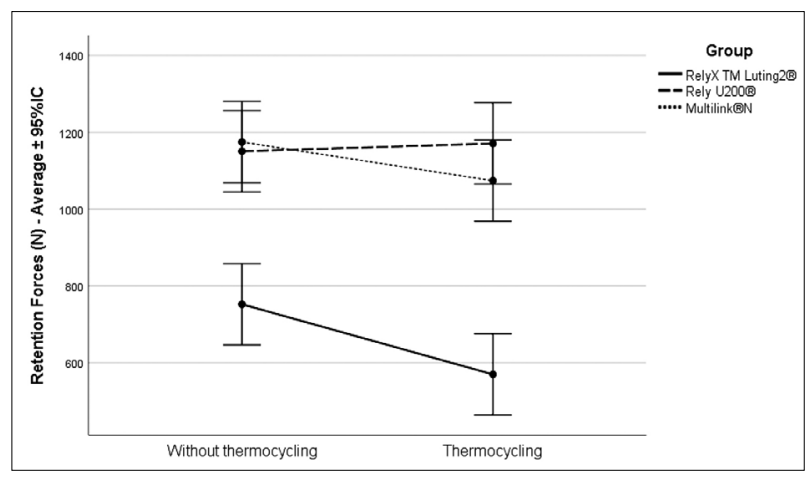

Fig. 2: Average values (95\% confidence interval) of tensile load in groups.

\section{Failure analysis after the tensile test}

When cementation was performed with RelyX Luting 2, the failures were predominantly adhesive, between the $\mathrm{Zr}$ coping and the cement (85.7\%). RelyX U200 presented failures predominantly due to screw fracture $(85.7 \%)$, with a minimum number of adhesive failures between the $\mathrm{Zr}$ coping and cement (14.3\%). In MultilinkN, all samples that were not thermocycled showed failures due to screw fracture $(100 \%)$, while in the group that underwent thermocycling $28.5 \%$ were adhesive failures between the $\mathrm{Zr}$ coping and cement (Fig. 3). 


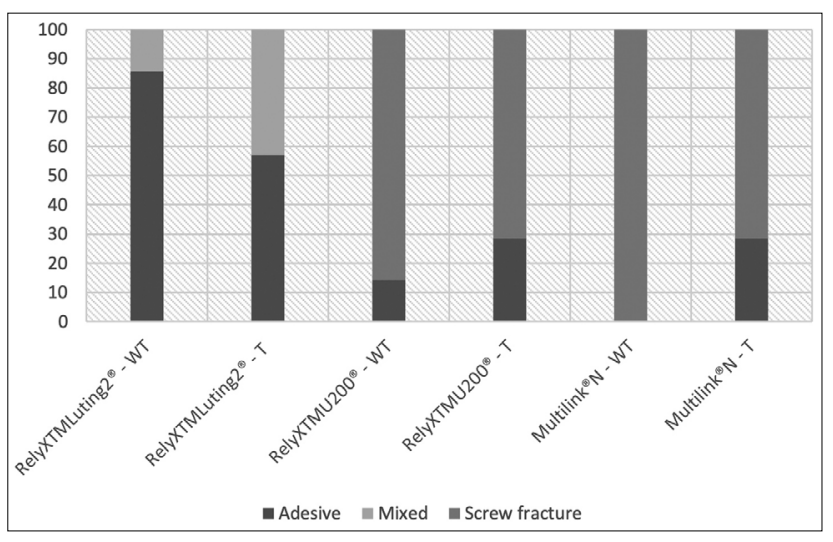

Fig. 3: Type of failure found in the evaluated groups (values in $\%)$.WT: Without thermocycling, T: Thermocycling

\section{DISCUSSION}

The results of tensile strength and longevity of the $\mathrm{Zr}$ coping cementation on the TiBase abutment found in this study are important to guide clinicians in choosing the type of cementation material. The results showed that the glass ionomer cement promoted lower tensile strength values than the resin cements, leading to the rejection of the first proposed null hypothesis. Another result was the significant decrease in tensile strength after thermocycling for the cements used, leading us to reject the second null hypothesis.

Resin cements are known to promote higher values of tensile strength than glass ionomer cements ${ }^{19}$. Resin cements have high shear strength to resist the internal forces that can cause the structure of the material to slide against itself. At the same time, they can withstand tensile forces, enabling the hydrophobic matrix of a composite cement to adhere to hydrophilic substrates ${ }^{20}$. Thus, better behavior of resin cement is also observed when $\mathrm{Zr}$ copings are cemented on TiBase abutments ${ }^{8}$, reaching higher levels of retention force.

Comparison of the tensile bond strength values of resin cements showed averages of 1160.55 and $1124.14 \mathrm{~N}$ respectively for the RelyX U200 and MultilinkN cements, and $660.94 \mathrm{~N}$ for the ionomer (RelyX Luting 2). Resin cements are composed of resinous monomers that provide adequate chemical adhesion as well as micromechanical adhesion to dental and metallic structures when compared to resin-modified glass ionomer cement ${ }^{19}$. Moreover, there is consensus in the literature that treating the $\mathrm{Zr}$ surface with ceramic primers can promote better adhesion of the organic particles of the cement with the inorganic particles of $\mathrm{Zr}^{13-22}$. This may explain the higher values of the retention forces for the resin cements tested in relation to the glass ionomer cement modified by resin.

Another aspect is the surface treatment of $\mathrm{Zr}$. Hansen et al. ${ }^{21}$ evaluated the importance of preparing $\mathrm{Zr}$ with jets of $\mathrm{AL}_{2} \mathrm{O}_{3}$ before cementation. Different authors have concluded that the use of $\mathrm{Zr}$ surface treatment significantly increases the quality of retention after cementation ${ }^{7,8,23,24}$. However, other studies have shown that abrasive air particles with $\mathrm{AL}_{2} \mathrm{O}_{3}$ can cause damage to the surface of $\mathrm{Zr}$, causing flaws and microcracks, compromising the mechanical strength of $\mathrm{Zr}^{25,26}$.

The literature also reports that a lack of application of adhesive systems between $\mathrm{Zr}$ structures and resin cements could decrease the bond strength of $\mathrm{Zr}$ structures on implants ${ }^{8,10,12}$. However, the increase in adhesion can only be improved by using surface treatments such as blasting, silanization, and use of adhesives next to resin cements containing phosphate groups ${ }^{26}$. The resin cements used in this study include phosphate groups in their composition, which together with the surface treatment could explain the better performance of both resin cements. The high holding force could also be the result of using a titanium abutment with retentive areas. The pillar used in this study had areas of roughness, which possibly guaranteed greater mechanical interlocking with cement. In fact, Güngör et al. ${ }^{14}$ used smooth abutments for cementing $\mathrm{Zr}$ structures and concluded that thermocycling added to the mechanical cyclic load and resulted in a significant decrease in tensile strength

Another aspect studied was the effect of aging by thermocycling. Thermocycling is well accepted as a form of aging, since in addition to hydrolytic degradation promoted by water, temperature changes, repeated expansion/contraction, and other stresses within a sample have a significant impact on tensile strength ${ }^{27}$.

In this study, the average retention for the tested cements was $1025.71 \mathrm{~N}$ for the groups without thermocycling and $938.05 \mathrm{~N}$ for the thermocycled groups, showing a significant decrease. In the individual analysis, the effect of thermocycling was found to be less on resin cements than on the resin-modified glass ionomer cement . Saleh et al. ${ }^{26}$ also used thermocycling for aging and found that resin cements are more resistant than other types of 
cements to its effects and maintain the integrity of the cement line.

Among the causes of this decrease are increased sorption and solubility, and less interaction with organic components. The absence of a resinous monomer in this type of cement can aggravate the low resistance to aging processes, fostering a weak connection between the cement and the $\mathrm{Zr}$ structure. This could also have promoted an increase in adhesive-type failures in this group . However, in resin cement, although thermocycling decreased the values of tensile strength, this did not promote a significant difference. This may be due to the use of adhesive systems that, in addition to the surface alteration of $\mathrm{Zr}$ with $\mathrm{AL}_{2} \mathrm{O}_{3}$ blasting, made the adhesion more stable even after an aging process, as shown in Figure 2 in the confidence interval line ${ }^{15,28}$. In the analysis of the type of failure, it was found that for the resin cements, the failures were predominantly of the screw fracture type $(82.1 \%)$, while with the use of glass ionomer cement, $28.5 \%$ of the failures were of the adhesive type between the $\mathrm{Zr}$ coping and cement. The increase in retentive strength in the groups where resin cements were used caused the predominance of failures due to screw fractures. The region most susceptible to fracture of the pillar screw is located at the junction between the threads and the neck ${ }^{29}$, and it was in this region where all fractures occurred in this experiment. Studies report that this type of fracture can be minimized by using thicker screws and with an apical indexer that helps in the stabilization of the prosthetic component ${ }^{30}$.

Another feature that could have caused an increase in such failures is the thickness of the cement film. In the present work, it was standardized at $40 \mu \mathrm{m}$ for all samples. According to the literature, when

\section{CORRESPONDENCE}

Dr. Rudys Rodolfo De Jesus Tavarez

Universidade Ceuma - UNICEUMA

Rua Josue Montello 01, Renascença II, São Luís Maranhão,

Cep. 65075-120

Brasil

rudysd@uol.com.br thicknesses of up to a maximum of $60 \mu \mathrm{m}$ are used, better results are obtained in tensile strength tests $^{8,10}$. This thickness of cement film, added with a retentive titanium pillar, probably caused the high retentive force.

Malthazan et $\mathrm{al}^{8}$ tested two resinous cementing agents, finding the best retention rates with preconditioning of the coping and application of a ceramic primer. The maximum average observed in one of the groups in their study was $598.6 \mathrm{~N}$, using a smooth titanium pillar $7.8 \mathrm{~mm}$ high and $3.4 \mathrm{~mm}$ wide and a $30 \mu \mathrm{m}$ cementation space.

Although studies have evaluated different materials for cementing $\mathrm{Zr}$ structures on TiBase abutments ${ }^{7,11,12,14,21}$, the cementation step is important to ensure the stability and longevity of the implantsupported prosthesis system, and the lack of a predictable protocol for cementation of $\mathrm{Zr}$ copings on TiBase abutments is still a limitation in this area. The results in this study will help the appropriate choice of cement for zirconia restorations on zirconia or TiBase abutments.

The methodology used in this study endeavored to simulate what is performed clinically in a standardized way, but the clinical condition of each patient can influence the final outcome and longevity of the restorations. It is known that in vitro studies provide limited information regarding the clinical performance of $\mathrm{Zr}$ copings on TiBase abutments; therefore, randomized clinical trials that show real clinical situations of the behavior of these cements in the oral cavity have yet to be conducted.

In conclusion, resin cement has better adhesive stability when cementing the $\mathrm{Zr}$ coping to the TiBase abutment. Thermocycling decreases the retentive strength of resin-modified ionomer cement.

DECLARATION OF CONFLICTING INTERESTS

The authors declare no potential conflicts of interest regarding the research, authorship, and/or publication of this article

\section{FUNDING}

None 


\section{REFERENCES}

1. Ortega R, Gonzalo E, Gomez-Polo M, Lopez-Suarez C et al. SEM evaluation of the precision of fit of CAD/CAM zirconia and metal-ceramic posterior crowns. Dent Mater J. 2017;36:387-393.

2. Sailer I, Zembic A, Jung R, Hämmerle C et al. Singletooth implant reconstructions: esthetic factors influencing the decision between titanium and zirconia abutments in anterior regions. Eur J Esthet Dent. 2007;2:296-310.

3. Degidi M, Artese L, Scarano A, Vittoria Perrotti V et al. Inflammatory infiltrate, microvessel density, nitric oxide synthase expression, vascular endothelial growth factor expression, and proliferative activity in peri-implant soft tissues around titanium and zirconium oxide healing caps. J Periodontol. 2006;77:73-80.

4. Baldassarri M, Hjerppe J, Romeo D, Fickl S et al. Marginal accuracy of three implant-ceramic abutment configurations. Int J Oral Maxillofac Implant. 2012;27:537-543.

5. Hjerppe J, Lassila LV, Rakkolainen T, Narhi T et al. Loadbearing capacity of custom-made versus prefabricated commercially available zirconia abutments. Int $\mathrm{J}$ Oral Maxillofac Implant. 2011;26:132-138.

6. Zembic A, Bosch A, Jung RE, Hammerle CHF et al. Five-year results of a randomized controlled clinical trial comparing zirconia and titanium abutments supporting single-implant crowns in canine and posterior regions. Clin Oral Implants Res. 2013;24:384-390.

7. Mehl C, Zhang Q, Lehmann F, Kern M. Retention of zirconia on titanium in two-piece abutments with selfadhesive resin cements. J Prosthet Dent. 2018;120:214-219.

8. von Maltzahn NF, Holstermann J, Kohorst P. Retention forces between titanium and zirconia components of twopart implant abutments with different techniques of sur- face modification. Clin Implant Dent Relat Res. 2016;18:735744.

9. Wismeijer D, Bragger U, Evans C, Kapos T et al. Consensus statements and recommended clinical procedures regarding restorative materials and techniques for implant dentistry. Int J Oral Maxillofac Implants. 2014;29 Suppl:137-140.

10. Conejo J, Kobayashi T, Anadioti E, Blatz M. Performance of $\mathrm{CAD} / \mathrm{CAM}$ monolithic ceramic Implant-supported restorations bonded to titanium inserts: A systematic review. Eur J Oral Implantol. 2017;10 Suppl 1:139-146.

11. Cavusoglu Y, Akça K, Gurbuz R, Cehreli MC. A pilot study of joint stability at the zirconium or titanium abutment/ titanium implant interface. Int J Oral Maxillofac Implants. 2014;29:338-343.

12. Kemarly K, Arnason SC, Parke A, Lien W et al. Effect of Various Surface Treatments on Ti-Base Coping Retention. Oper Dent. 2020; 45:426-434.

13. Lopes A, Machado C, Bonjardim L, Bergamo E et al. The Effect of CAD/CAM Crown Material and Cement Type on Retention to Implant Abutments. J Prosthodont. 2019;28:e552-e556.

14. Güngör MB and Nemli SK. The effect of resin cement type and thermomechanical aging on the retentive strength of custom zirconia abutments bonded to titanium inserts. Int $\mathrm{J}$
Oral Maxillofac Implants. 2018;33:523-529.

15. Gehrke P, Alius J, Fischer C, Erdelt KJ et al. Retentive strength of two-piece CAD/CAM zirconia implant abutments. Clin Implant Dent Relat Res. 2014;16:920-925.

16. Mehl C, Harder S, Steiner M, Vollrath O et al. Influence of cement film thickness on the retention of implant-retained crowns. J Prosthodont. 2013;22:618-625.

17. Khan AA, Al Kheraif AA, Jamaluddin S, Elsharaw M et al. Recent trends in surface treatment methods for bonding composite cementto zirconia: A Review. J Adhes Dent. 2017;19:7-19.

18. Jun K, Yasuhiro H, Yukimichi T, Atushi O et al. Effect of sintering on the marginal and internal fit of CAD/CAM fabricated zirconia frameworks. Dent Mater J. 2007;26:820826.

19. Manso AP, Carvalho RM. Dental cements for lutting and bonding restaurations: Self adhesive resin cements. Dent Clin North Am. 2017;61:821-834.

20. Attia A. Bond strength of three luting agents to zirconia ceramic - influence of surface treatment and thermocycling. J Appl Oral Sci. 2011;19:388-395.

21. Hansen NA, Wille and Kern M. Effect of reduced airborne particle abrasion pressure on the retention of zirconia copings resin bonded to titanium abutments. J Prosthet Dent. 2020;124:60-67.

22. Bielen V, Inokoshi M, Munck JD, Zhang F et al. Bonding effectiveness to differently sandblasted dental zirconia. J Adhes Dent. 2015; 17:235-342.

23. Attia A, Kern M. Effect of cleaning methods after reducedpressure air abrasion on bonding to zirconia ceramic. J Adhes Dent. 2011;13:561-567.

24. Koizuka M, Komine F, Blatz MB, Fushiki R et al. The effect of different surface treatments on the bond strength of a gingiva-colored indirect composite veneering material to three implant framework materials. Clin Oral Implants Res. 2013;24:977-984.

25. Elsaka SE. Influence of surface treatments on the bond strength of resin cements to monolithic zirconia. J Adhes Dent. 2016;18:387-395.

26. Saleh $M$ and Tasar-Faruk. Comparing the marginal leakage and retention of implant-supported restorations cemented by four different dental cements. Clin Implant Dent Relat Res. 2019;21:1181-1188.

27. Ozcan M, Bernasconi M. Adhesion to zirconia used for dental restorations: A systematic review and meta-analysis. J Adhes Dent. 2015;17:7-26.

28. Putra, Chung K H, Guilherme N M, Cagna D R. Effect of bonding and rebonding on the shear bond strength of twopiece implant restorations. J Prosthodont. 2019;28:305-309.

29. Khraisat A, Stegaroiu R, Nomura S, Miyakawa O. Fatigue resistance of two implant/abutment joint designs. J Prosthet Dent. 2002;88:604-610.

30. Piermatti J, Yousef H, Luke A, Mahevich R et al. An in vitro analysis of implant screw torque loss with external hex and internal connection implant systems. Implant Dent. 2006;15:427-435. 